\title{
Impact of Intellectual Capital on Microfinance Institutions' Efficiency: the Moderating Role of External Governance
}

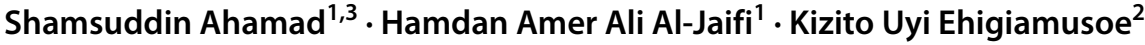

Received: 30 January 2021 / Accepted: 14 January 2022

(C) The Author(s), under exclusive licence to Springer Science+Business Media, LLC, part of Springer Nature 2022

\begin{abstract}
This study examines the impact of intellectual capital (IC) and its components (human capital, structural capital, and capital employed) on microfinance institutions' (MFIs) financial and social efficiency. It also determines the moderating impact of external governance on the relationship between IC and MFIs' financial and social efficiency. It employs the Truncated regression model and Data Envelopment Analysis (DEA), while the Tobit model and Generalized Method of Moments (GMM) were utilized to check the robustness of the estimations. The study uses panel data of 661 MFIs from 86 countries covering 2010-2018 period. The study shows that MFIs are financially efficient rather than socially efficient, albeit MFIs that have high IC can be more financially efficient. Besides, good external governance positively moderates the impact of IC on financial efficiency. The three components of IC have significant effect on MFIs' financial efficiency, albeit external governance has a significant moderating role on the relationship between value of capital employed and financial efficiency only. As for the social outreach efficiency, this study indicates that IC has a significant positive impact on social outreach efficiency, while external governance has no significant moderating effect on the nexus between IC and MFIs' social outreach efficiency. The empirical outcomes of this study have useful implications for MFIs' decision-makers and regulators regarding the need to consider intellectual capital in their quest to enhance the MFIs' efficiency.
\end{abstract}

Keywords Intellectual capital · Microfinance institutions · Financial efficiency · Social outreach efficiency $\cdot$ External governance

Shamsuddin Ahamad

shamsuddinahamad@sd.taylors.edu.my; shamsuddin.ahamad@ulab.edu.bd

1 Taylor's Business School, Taylor's University Malaysia, Subang Jaya, Selangor, Malaysia

2 Southampton Business School, University of Southampton Malaysia, Johor, Malaysia

3 School of Business, University of Liberal Arts, Dhaka, Bangladesh

Published online: 31 January 2022 


\section{Introduction}

Intellectual capital (IC) is the key driver of a knowledge-intensive economy and organizational competitiveness (Adnan et al., 2013). Though the IC is considered as part of the company's capital, it is not reflected accurately in its financial statements. IC generates a future value for a company and give it a competitive advantage over its competitors. Recently, microfinance industry has been facing intense competition than ever before (Hossain et al., 2020; Mia \& Soltane, 2016). With 139.9 million low-income and underserved clients and about $11.5 \%$ annual global growth rate, microfinance institutions (MFIs) are trying to attain their financial stability and social outreach goal (Microfinance Barometer Report, 2019). Unfortunately, empirical evidence shows that many MFIs can cover only a quarter of their expenses, and almost half of the world's MFIs are still unprofitable (Guichandut, 2018; Turini, 2018).

Moreover, MFIs' expansion in outreach to new clients has been fluctuating steadily in recent years. Compared to the global scenario, microfinance expansion has plummeted in some regions. For example, the Middle East and North Africa (MENA) and Africa region experienced reduction while the Latin America and Caribbean region exhibit negative growth by $-0.3 \%$ (Microfinance Barometer Report, 2019). Besides, some studies indicated that most of the MFIs are financially and socially incompetent (Babu-Muneer \& Kulshreshtha, 2017; Nourani et al., 2020; Wijesiri et al., 2017; Wijesiri \& Meoli, 2015). Thus, the overall condition in financial stability and client outreach threatens the viability of MFIs' sector. This situation also raises a question about the efficiency of the MFIs. Hence, this study aims to evaluate the MFIs' financial and social outreach efficiency in-depth with a view to guiding their continuous development and sustainability.

Previous studies have focused on a limited number of inputs and outputs to measure financial efficiency or social outreach efficiency. Most of the studies used operating expenses, total assets, and the staff size as input variables for both efficiencies. This study upholds these same inputs and uses the two output variables frequently used in the literature to assess financial efficiency such as financial revenue and gross loan portfolio (Bibi et al., 2018; Gutierrez-Goiria et al., 2017; Widiarto \& Emrouznejad, 2015). As for social efficiency, Hermes and Hudon (2018) argued that social efficiency should be measured with multidimensional perspectives instead of using a single dimension. Aligned with this argument, borrowers' geographical location and number of depositors are included as new social outreach indicators in addition to the existing indicators such as average loan balance/GNI per capita, total existing borrowers, and female borrowers. This study examines the efficiency using these input and output variables under the production approach. It incorporates the renowned data analysis tool namely, Data Envelop Analysis (DEA) to provide more robust efficiency results.

The literature on the determinants of MFIs' efficiency has not provided sufficient empirical evidence (Fall et al., 2018; Kar \& Rahman, 2018). Very few studies have assessed the determinants of efficiency in a second-step statistical 
analysis (Adusei, 2019; Bibi et al., 2018; Gutiérrez-Nieto et al. 2009; Hermes et al., 2011; Widiarto \& Emrouznejad, 2015; Wijesiri et al., 2017; Wijesiri \& Meoli, 2015). The studies mainly used the traditional determinants such as the size of MFIs and gender diversity. Thus, there is scope to examine some other important determinants that can explain the variations in efficiency estimates. The literature on banking and other financial and non-financial industry shows that intellectual capital is a potential determinant that improves firm performance. In microfinance literature, intellectual capital studies are still scanty except Hashim et al. (2018) and Kamukama et al. (2010). Both studies were conducted based on primary survey data from a single-country perspective (Malaysia and Uganda). Therefore, this study seeks to provide answers to the following question: What is the impact of intellectual capital on microfinance institutions' financial and social outreach efficiency?

Theoretically, the components of IC are human capital, structural capital, and relational capital (Vidyarthi \& Tiwari, 2019). These elements are essential for any organization to become an aligned and a balanced organization, thereby creating the best possible value for its sustainable operation. For instance, Ahamad et al. (2020) stated that human capital could significantly affect business performance. Several studies supported the hypothesis that human capital, structural capital, and relational capital have significant effects on firm performance in the banking and other industry (Kamukama et al., 2010; Vidyarthi \& Tiwari, 2019; Xu \& Li, 2019; Yalama \& Coskun, 2007). Hence, it is necessary to examine the extent to which these IC elements influence the microfinance industry's financial and social outreach efficiency.

Furthermore, Pinz and Helmig (2015) and Hermes and Hudon (2018) argued that previous studies examined the direct effect of country governance variables on MFIs' performance, while the potential interaction effect is overlooked. Besides, the empirical outcomes on the direct effect are mixed. For example, Bibi et al. (2018) found a positive direct impact of country governance variables on MFIs' financial and social performance. However, Müller and Uhde (2013) found that external governance has a positive impact on financial performance while social performance is negatively influenced by external governance. However, some studies suggested that country governance variable could play a significant moderating role (Hermes \& Hudon, 2018; Pinz \& Helmig, 2015). Hence, this study also seeks to fill the research gaps by addressing the following questions: Does external governance have a significant positive moderating effect on the impact of intellectual capital on microfinance institutions' financial and social outreach efficiency?

Hence, the contribution of this study is threefold. First, since the literature on intellectual capital postulated that the components of IC (i.e., human capital, structural capital, and relational capital) could empower organizations to improve institutional efficiency (Kamaluddin \& Rahman, 2013; Majumder, 2012; Vidyarthi \& Tiwari, 2019; Xu \& Li, 2019; Yalama \& Coskun, 2007), this study extends these theoretical arguments to the microfinance industry. It tests the theoretical predictions by examining the impact of IC on microfinance institutions' financial and social outreach efficiency. Furthermore, the Resource-Based View (RBV) theory posits that business performance can be improved as well as gain a sustainable competitive 
advantage if the firm has valuable resources (Wernerfelt, 1984). Thus, this study makes theoretical contribution to the literature by focusing on IC and its elements as intangible resources from the RBV theory. Moreover, intellectual capital theory opines that an organization could attain success by managing intellectual capital effectively (Edvinsson \& Malone, 1997; Stewart, 1997). This study also seeks to validate this theory in the field of microfinance. Second, unlike other studies that focused on the effect of IC on firms' financial stability, this study also examines the impact of IC on MFIs' social outreach efficiency. Third, it contributes to the extant literature by incorporating external country governance as a moderating variable in the relationship between IC and the MFIs' efficiency.

To address the above issues, the current study used data of 661 MFIs from 86 countries from 2010 to 2018. The first stage result using the DEA technique shows that MFIs are financially efficient rather than socially efficient. The second-stage regression analyses confirm that MFIs with high IC can be more financially efficient. Besides, good external governance has a positive moderating effect on the impact of IC on financial efficiency. It also shows that IC influences social outreach efficiency, albeit external governance has no significant moderating effect on the impact of IC on social efficiency. Evidence from the analysis of the IC components confirm that these components play significant roles in microfinance's efficiency.

Apart from this introduction, the rest of the paper is structured as follows: the "Literature Review" section discusses the literature review; the "Methodology and Data" section contains the methodology and data; the "Findings and Discussions" section presents the findings and discussion; the "Implications and Recommendations" section presents the implications and recommendations; and the "Conclusion" section contains the conclusion, limitations of the study, and suggestions for future research.

\section{Literature Review}

\section{Intellectual Capital and Efficiency}

Intellectual capital (IC) is considered as the heart of a knowledge-based economy (Khalique et al., 2013). IC is the sum of a company's intangible assets that help them to achieve greater performance (Brooking, 1996; Stewart, 1997). IC empowers organizations and enhances their capacities to implement strategies to improve institutional efficiency (Amrizah \& Rashidah, 2013; Majumder, 2012). For instance, Edvinsson and Malone (1997), who developed the intellectual capital theory, advocated that an organization can create a good financial value if it can properly use IC in their firms' operations. Stewart (1997) agreed that an organization could bring its success by managing intellectual capital effectively. Moreover, the Resource-Based View (RBV) theory posits that business performance can be improved once the firm has precious resources. A firm's resources (e.g., attributes, capacities, organizational structures, information, and knowledge) enable it to gain sustainable competitive advantage to increase its proficiency and adequacy (Barney, 1991). These resources 
could be a combination of human capital, organizational capital, and physical capital (Ahamad et al., 2020). Based on this theory, Wernerfelt (1984) stated that intellectual capital is an important and potential resource for firm's performance.

Some empirical studies indicate that IC has a vital and favorable impact on financial performance in the banking and other industries (Adesina, 2019; Bayraktaroglu et al., 2019; Soewarno \& Tjahjadi, 2020). Specifically, Adesina (2019) and Soewarno and Tjahjadi (2020) concluded that IC positively affects banks' financial performance while $\mathrm{Xu}$ and $\mathrm{Li}$ (2019) found similar outcome in Chinese high-tech companies. Using data from different countries and perspectives, some studies have provided empirical evidence to support the positive impact of IC on firm's efficiency (Ozkan et al., 2017; Vidyarthi \& Tiwari, 2019; Yalama \& Coskun, 2007). However, empirical research on the nexus between IC and MFIs' efficiency is still scanty albeit Hashim et al. (2018) and Kamukama and Sulait (2017) used primary survey data to indicate that intellectual capital positively influences MFIs' performance in Uganda and Malaysia, respectively. From the foregoing discussions on the intellectual capital theory, RBV, and empirical evidence, this study proposes the following hypotheses:

$\mathrm{H}_{1}$ : Intellectual capital has a positive and significant impact on financial efficiency of MFIs.

$\mathrm{H}_{2}$ : Intellectual capital has a positive and significant impact on social outreach efficiency of MFIs.

Though it is evident from the literature that firm performance is positively influenced by IC, the individual effect of IC components (human capital, structural capital, and relational capital) on firm performance is mixed (Vidyarthi \& Tiwari, 2019). Human capital is identified as the greatest and most necessary intangible asset of a business enterprise (Hashim et al., 2018). Human capital is also an essential building block of business performance (Ahamad et al., 2020). It is related to training, education, and the additional professional activities that develop employees' knowledge, skills, values, and social assets, which enhance the employee's satisfaction and performance and ultimately enhance the firm's performance (Ahamad et al., 2016; Baron, 2011). Besides, Majumder (2012) noted that human capital is an essential source for institutions that increase their efficiency and sustainability. Human capital can also consist of credit disbursement employees to office executives, managers to CEO, and directors. Ahamad et al. (2020) stated that firms' growth and profitability could be higher using all the types of human capital appropriately in their operations.

Structural capital can be defined as the knowledge acquired in a company but not owned by employees such as systems, structures, strategies, patents, trademarks, culture, and principles that create innovative opportunities for the organization (Ling, 2012; Nimtrakoon, 2015). In other words, an organization consists of important resources such as inner structures and workforce. Consequently, structural capital is also denoted as the organization's ability to meet its customers' needs. When a company ensures its technological progress, update their system continuously, and develop its inside resources, the structural capital increases. Amrizah and Rashidah (2013) advocated that a well-organized structure improves microfinance institutions' 
efficiency with the help of qualified staff providing their efficient and high-quality services. Khalique et al. (2015) argued that if the organization has a knowledgeable and competent staff but provides less potential structural capital, it is assumed that all intellectual capital is not fully and properly utilized.

Relational capital is better known as customer capital, and it is recognized as the connection between employees, customers, sourcing partners, and competitors (Bontis et al., 2000; Ling, 2012). This connection with good relations and satisfaction signifies company loyalty. Al-Shami et al. (2013) documented from their study conducted in Malaysia that relational capital positively influences the customers' well-being that ultimately ensures the institution's efficiency. Relational capital includes advertising costs and other related expenditure to keep communication with related stakeholders. As most of the MFIs operate as NGO and small-size financial institutions, they do not spend money on advertising. Thus, these expenditures are absent in MFIs' annual data (World Bank, 2019a). Instead, some studies used asset value as capital employed in the firm's operation as an IC component (Bayraktaroglu et al., 2019; Vidyarthi $\&$ Tiwari, 2019). The higher value of this capital employed creates higher value for the firms (Vidyarthi \& Tiwari, 2019). However, these three elements of intellectual capital, namely, human capital (HC), structural capital (SC), and capital employed (CE), enhance the companies' competitiveness, thereby contributing to developing the knowledge-based economy (Adnan et al., 2013). Therefore, the intellectual capital theory says that an organization can create a good financial value if it can establish and balance these three important elements (Edvinsson \& Malone, 1997). From the foregoing discussions, and consistent with the theoretical and empirical arguments, this study proposes the following hypotheses:

$\mathrm{H}_{1 \mathrm{a}}$ : Human capital has a positive and significant effect on the financial efficiency of MFIs.

$\mathrm{H}_{1 \mathrm{~b}}$ : Structural capital has a positive and significant effect on the financial efficiency of MFIs.

$\mathrm{H}_{1 \mathrm{c}}$ : Capital employed has a positive and significant effect on the financial efficiency of MFIs.

$\mathrm{H}_{2 \mathrm{a}}$ : Human capital has a positive and significant effect on the social outreach efficiency of MFIs.

$\mathrm{H}_{2 \mathrm{~b}}$ : Structural capital has a positive and significant effect on the social outreach efficiency of MFIs.

$\mathrm{H}_{2 \mathrm{c}}$ : Capital employed has a positive and significant effect on the social outreach efficiency of MFIs.

\section{Intellectual Capital, External Governance, and Efficiency}

The microfinance industry requires a good governance structure. Nowadays, it is more crucial since the microfinance industry can be affected by country weak governance structure. The 2010 problems in India, for instance, affected the overall performance of the MFIs (Taylor, 2011). Thus, a good governance structure could strengthen the performance of MFIs. Churchill (2018) posited that the 
performance of MFIs could vary across countries depending on their country governance structure. The governance structure of a country can be assessed by six different aspects of the World Governance Indicator (WGI) such as the regulatory quality, government effectiveness, the rule of law, control of corruption, political stability, and voice and accountability (Churchill, 2018).

The regulatory environment of a country is essential for MFIs' sustainability and outreach. Studies conducted by Bassem (2008) and Emeni (2008) claimed that a regulatory environment is positively associated with MFIs' financial performance. Some studies conducted by Bassem (2008), Boehe and Cruz (2013), and Gohar and Batool (2015) found that social performance is influenced by financial roles and regulations. On the other hand, Anku-Tsede (2014), Bakker et al. (2014), Halouani and Boujelbene (2015), and Pati (2015) argued that more regulatory restrictions could hinder MFIs instead of supporting them in a cost-effective way to support poor people with the provision of financial services. Besides the regulation, political instability is another indicator that increases the business financial risk. Ault and Spicer (2014) stated that in weak states, MFIs experience poor financial performance though have better social performance. Furthermore, SainzFernandez et al. (2015) demonstrated that political stability can reduce the crises, and accelerate the MFIs' performance. Hermes and Hudon (2018) argued that the political system is part of the country's institutional context, and political stability may increase the demand for services from MFIs. Thus, it can help to reach the poor people and consequently enhance the MFIs' social outreach goal. Moreover, a better rule of law also can reduce the financial crisis and help business growth (Quayes \& Joseph, 2017). The arguments are consistent with the findings in the microfinance area conducted by Ashta and Fall (2012).

Overall, the empirical evidence demonstrates that country good governance is essential for MFIs' growth and expansion. Therefore, previous studies measured the relationship between good governance and business performance as a direct relationship. Pinz and Helmig (2015) argued that country contextual variables typically have a moderating impact. Hermes and Hudon (2018) corroborated the argument and admitted that the direction of the relationship between drivers and MFIs performance depends on the context. Particularly, country governance factors may play a significant moderating role. Thus, this study wants to fill the gaps by incorporating external country governance factors as moderating variables in the relationship between intellectual capital (its components) and the MFIs' financial and social efficiency. Hence, it proposes the following hypotheses:

$\mathrm{H}_{3}$ : External governance has a significant moderating effect on the relationship between intellectual capital and MFIs' financial efficiency.

$\mathrm{H}_{3 \mathrm{a}}$ : External governance has a significant moderating effect on the relationship between human capital and MFIs' financial efficiency.

$\mathrm{H}_{3 \mathrm{~b}}$ : External governance has a significant moderating effect on the relationship between structural capital and MFIs' financial efficiency.

$\mathrm{H}_{3 \mathrm{c}}$ : External governance has a significant moderating effect on the relationship between capital employed and MFIs' financial efficiency. 
$\mathrm{H}_{4}$ : External governance has a significant moderating effect on the relationship between intellectual capital and MFIs' social outreach efficiency.

$\mathrm{H}_{4 \mathrm{a}}$ : External governance has a significant moderating effect on the relationship between human capital and MFIs' social outreach efficiency.

$\mathrm{H}_{4 \mathrm{~b}}$ : External governance has a significant moderating effect on the relationship between structural capital and MFIs' social outreach efficiency.

$\mathrm{H}_{4 \mathrm{c}}$ : External governance has a significant moderating effect on the relationship between capital employed and MFIs' social outreach efficiency.

\section{Methodology and Data}

\section{Data and Sample}

To examine the efficiency of MFIs, this study uses secondary data obtained from the "Microfinance Information Exchange (MIX)." This MIX is the only reliable database that contains valuable financial and social outreach information of MFIs. In late 2019, MIX collaborated with World Bank and released its database through the World Bank data catalog for free. Thus, an unbalanced data of 661 MFIs from 86 countries for the period of 2010-2018 were obtained from that database. To reach this sample and the period, some conventional criteria were executed such as removal of the missing value in line with Mia (2020) and Nourani et al. (2020). It was necessary as the efficiency estimate technique does not accept missing values throughout the sample period. Due to unavailability of the data, 2019 and 2020 were excluded from the analysis. Furthermore, the World Governance Indicators (WGI) database provided the data for external governance variables. These governance indicators scaled at -2.5 to +2.5 , where -2.5 represents very weak governance quality and +2.5 represents very well (World Bank, 2019b). Moreover, data for the control variables such as inflation rate and GDP per capita growth were sourced from the World Development Indicators (WDI) database.

\section{Measuring Efficiency Modeling}

Frontier-based efficiency analysis is often used in recent studies as a modern technique compared to the traditional ratio method. Parametric and non-parametric analyses are the types of frontier-based efficiency analyses. Therefore, this study uses the non-parametric method "Data Envelop Analysis (DEA)." One of the essential advantages over other methods is that DEA can use more than one input and more than one output in the distribution and production function except for any prior assumption (Akçay et al., 2012; Cooper et al., 2011).

Production and intermediation are the two common approaches used in the literature to select input and output variables. In the production approach, institutions use capital and labor as input to produce loans, deposits, and other services as output. On the other hand, institutions play a role in transferring wealth. They use savings/ deposits to produce loans and other services as output. Since this study seeks to 
Table 1 Mathematical formulation of financial and social efficiency

\begin{tabular}{ll}
\hline Financial efficiency (Equation(1)) & Social efficiency (Equation(2)) \\
\hline$\theta, \lambda j^{\min } \theta$ & $\theta, \lambda j^{\max } \theta$ \\
Subject to: & Subject to \\
$\sum_{j=1}^{n} \lambda_{j} Y_{r j} \geq Y_{r j}(Y$ is output, $r=1, \ldots \ldots, s)$ & $\theta Y_{j}+\lambda_{j} Y_{r j} \geq 0$ (Output is $\left.Y, r=1, \ldots, s\right)$ \\
$\theta X_{i j} \geq \sum_{j=1}^{n} \lambda_{j} X_{i j} \geq Y_{r j}(X$ is input, $i=1, \ldots, m)$ & $X_{i}-\lambda_{j} X_{i j} \geq 0$ (Input is $\left.X, I=1, \ldots, m\right)$ \\
$\sum_{j=1}^{n} \lambda j=1(\mathrm{FIs}, j=1 \ldots, n)$ & $\sum_{j=1}^{n} \lambda j=1$ (MFIs, $\left.j=1 \ldots, n\right)$ \\
$\lambda_{j} \geq 0$ & $\lambda_{j} \geq 0$ \\
Input-oriented model & Output-oriented model \\
\hline
\end{tabular}

determine the social outreach in the form of the number of borrowers and the depositor's scenario, the production approach is selected. Thus, aligned with the production approach, this study selects three input variables, namely, operating expenses, number of staff, and total assets. Two output variables selected include financial revenue and gross loan portfolio for financial efficiency. Five output variables selected are the number of active borrowers, the number of women borrowers, and average loan balance/GNI per capita used by Nourani et al. (2020), Bibi et al. (2018), Mia and Chandran (2016), and Widiarto and Emrouznejad (2015). Moreover, the number of savers and rural outreach was introduced for social efficiency following the suggestion given by Hermes and Hudon (2018).

There are two assumptions regarding DEA modeling. The first one is input-oriented, and the second one is the output-oriented model. The input-oriented model assumes that input should reduce while the output level will be constant. The output-oriented model assumes attempt to increase output while the input level is fixed. Since this study uses the number of borrowers as an output for social efficiency, the use of an outputoriented model is more appropriate. Input-oriented model for financial efficiency applied gross loan portfolio and financial revenue used as output variables.

The DEA modeling varies based on the Constant Returns to Scale (CRS), also known as CCR, and Variable Return to Scale (VRS) also known as BCC. The CRS model is applicable if we assume that the returns to scale are constant; otherwise, the VRS is desirable. Due to the variation in the size of the existing microfinance institutions, the VRS method is chosen. Thus, the following DEA equations are formulated based on the input-oriented and output-oriented model using variable return to scale (Table 1).

\section{Measurement of Intellectual Capital}

The value-added intellectual capital (VAIC) method is applied to calculate intellectual capital founded by Pulic (1998). VAIC method is formulated as follows:

$$
\mathrm{VAIC}=\mathrm{CEE}+\mathrm{HCE}+\mathrm{SCE}
$$

To calculate the VAIC, the value generated by the firm (VA) needs to be computed first. VA is defined as follows (Pulic, 2004): 


$$
\mathrm{VA}=\text { Operating Income }+ \text { Labor Expenses }+ \text { Depreciation }+ \text { Amortization }
$$

Here, staff or workforce are perceived as a resource in this formula, not as a cost due to their active contribution to VA formation.

Next, CEE indicates how efficiently a company uses its financial capital to create value. CEE is estimated as the proportion of VA and total CE.

$$
\mathrm{CEE}=\mathrm{VA} / \mathrm{CE}
$$

Here, CE is obtained as the book value of the organization's net assets.

HCE is computed as the proportion of the total VA divided by the total salary and wages that the company spends on its staff. HCE is defined as follows:

$$
\mathrm{HCE}=\mathrm{VA} / \mathrm{HC}
$$

Human capital and structural capital have an invert contribution in value creation, suggesting that "the less human capital participates in value creation, the more structural capital is involved" (Pulic, 2000). Based on this argument, the difference between VA and human capital is SC $(\mathrm{SC}=\mathrm{VA}-\mathrm{HC})$. Moreover, to define SCE, Pulic (2000) asserted that the SC is the share of created value.

$$
\mathrm{SCE}=\mathrm{SC} / \mathrm{VA}
$$

\section{Regression Models}

This study examines the determinants of efficiency with the Truncated regression model, following the estimation of DEA efficiency scores (bounded from 0 to 1). Simar and Wilson (2007) suggested the use of the Truncated regression model to overcome the traditional OLS model's weakness. The authors argued that the efficiency score so derived in the first stage might serially be correlated. Furthermore, if the sample size is small, it is possible to strongly correlate the input/output variables and error terms with the environmental variables. These weaknesses could lead to a biased estimation of the relationship between the efficiency score and explanatory variables. Sinha and Pandey (2019) asserted that the Truncated regression approach is effective as it removes serial correlation. Thus, following these arguments, this study employs the Truncated regression model in line with some studies (Bibi et al., 2018; Wijesiri et al., 2017). The following regression models are specified for both financial and social efficiency.

$$
\begin{aligned}
& \mathrm{FINE}_{i t}=\beta_{0}+\beta_{1} \mathrm{VAIC}_{i t}+\beta_{2} \mathrm{Size}+\beta_{3} \mathrm{WGI}+\beta_{4} \mathrm{INF}+\beta_{5} \mathrm{GDP}+\beta_{6} \mathrm{CYR}+\epsilon_{i t} \\
& \mathrm{FINE}_{i t}=\beta_{0}+\beta_{1} \mathrm{HCE}_{i t}+\beta_{2} \mathrm{Size}+\beta_{3} \mathrm{WGI}+\beta_{4} \mathrm{INF}+\beta_{5} \mathrm{GDP}+\beta_{6} \mathrm{CYR}+\epsilon_{i t} \\
& \mathrm{FINE}_{i t}=\beta_{0}+\beta_{1} \mathrm{SCE}_{i t}+\beta_{2} \mathrm{Size}+\beta_{3} \mathrm{WGI}+\beta_{4} \mathrm{INF}+\beta_{5} \mathrm{GDP}+\beta_{6} \mathrm{CYR}+\epsilon_{i t} \\
& \mathrm{FINE}_{i t}=\beta_{0}+\beta_{1} \mathrm{CEE}_{i t}+\beta_{2} \mathrm{Size}+\beta_{3} \mathrm{WGI}+\beta_{4} \mathrm{INF}+\beta_{5} \mathrm{GDP}+\beta_{6} \mathrm{CYR}+\epsilon_{i t}
\end{aligned}
$$


where FINE represents the financial efficiency score of the MFIs, VAIC represents value-added intellectual capital, HCE denotes human capital, SCE denotes structural capital, and CEE represents the value added by capital employed. The control variables are Size, WGI, INF, GDP, and CYR. Size represents the natural logarithm of total assets, WGI denotes the world governance indicator estimate (that signify the governance performance) ranging from -2.5 (weak) to 2.5 (strong), INF represents the country's inflation rate, GDP represents growth rate of real GDP per capita, and CYR represents the country-year effect. $\beta_{1}$ to $\beta_{6}$ are the coefficients of the variables, $i$ is the institution, $t$ is the year, and $\epsilon_{i t}$ is the error term.

This study focuses on the impact of IC on MFIs' efficiency. To capture MFIs' efficiency, it employs financial efficiency and social efficiency models. The justification for using two models is that MFIs have both financial sustainability and social orientation objectives. Therefore, a comprehensive analysis of MFIs' efficiency should consider both financial and social outreach efficiency. Secondly, recent evidence have shown that MFIs' outreach expansion to new clients is declining across the globe (Microfinance Barometer Report, 2019). Besides, empirical evidence indicated that many MFIs could cover only a quarter of their expenses, and almost half of the world's MFIs are still unprofitable (Guichandut, 2018; Turini, 2018). This overall condition in financial sustainability and social outreach necessitated the analysis of both models to determine ways to improve the scenario. Third, since IC is considered as a potential factor that creates financial value for the company and helps to reach the outreach goal, this study examines the effect of IC on both the financial and social efficiency dimensions. Finally, the dearth of literature on the impact of IC on the microfinance industry motivates this study to advance the microfinance literature by incorporating both financial and social outreach efficiency.

Therefore, similar models are specified with social outreach efficiency as the dependent variable as follows:

$$
\begin{aligned}
& \mathrm{SOCE}_{i t}=\beta_{0}+\beta_{1} \mathrm{VAIC}_{i t}+\beta_{2} \mathrm{Size}+\beta_{3} \mathrm{WGI}+\beta_{4} \mathrm{INF}+\beta_{5} \mathrm{GDP}+\beta_{6} \mathrm{CYR}+\epsilon_{i t} \\
& \mathrm{SOCE}_{i t}=\beta_{0}+\beta_{1} \mathrm{HCE}_{i t}+\beta_{2} \mathrm{Size}+\beta_{3} \mathrm{WGI}+\beta_{4} \mathrm{INF}+\beta_{5} \mathrm{GDP}+\beta_{6} \mathrm{CYR}+\epsilon_{i t} \\
& \mathrm{SOCE}_{i t}=\beta_{0}+\beta_{1} \mathrm{SCE}_{i t}+\beta_{2} \mathrm{Size}+\beta_{3} \mathrm{WGI}+\beta_{4} \mathrm{INF}+\beta_{5} \mathrm{GDP}+\beta_{6} \mathrm{CYR}+\epsilon_{i t}
\end{aligned}
$$

$$
\mathrm{SOCE}_{i t}=\beta_{0}+\beta_{1} \mathrm{CEE}_{i t}+\beta_{2} \mathrm{Size}+\beta_{3} \mathrm{WGI}+\beta_{4} \mathrm{INF}+\beta_{5} \mathrm{GDP}+\beta_{6} \mathrm{CYR}+\epsilon_{i t}
$$

where SOCE represents the social efficiency score of the MFIs.

In addition to the baseline models, the Tobit regression model and the Generalized Method of Moments (GMM) are employed for robustness checks. Tobit regression is used because it is appropriate when the dependent variable is censored on the left, right, or both sides, and the magnitude of efficiency scores ranges from 0 to 1 . The Tobit model is a better fit for robustness check since MFIs' financial and social outreach efficiency scores are censored left and right, ranging between 0 and 1. Another advantage of using the Tobit model is that it produces unbiased coefficient estimates compared to the Ordinary Least Squares (OLS) regression method 
(McCarty \& Yaisawarng, 1993). Furthermore, the GMM estimator is used to check for robustness because it can control potential endogeneity in dynamic panel model with the lagged dependent variable. It can also control for correlation between the explanatory variables and the error term in a model. Besides, the GMM can deal with omitted variable bias, unobserved panel heterogeneity, and measurement errors (Roodman, 2009). Moreover, the GMM estimator uses instruments (instrumental variables) because of the existence of correlation between the lagged dependent variable and the error term. Blundell and Bond (1998) proposed using appropriate lags of dependent and independent variables as instruments to solve this problem. Arellano and Bover (1995) also suggested that endogeneity can be corrected by introducing an instrumental variable to improve efficiency. However, these instruments should be validated using some tests (e.g., Hansen test of over-identifying restrictions). To verify the consistency of the GMM estimator, our study uses two tests, namely, the Hansen test of over-identifying restriction and the Arellano and Bond test for autocorrelation. The Hansen test is used to test the joint validity of the instruments and the test indicates that the instruments are jointly valid. The Arellano and Bond test is used to test for the presence of first-order and second-order serial correlation, and the test reveals absence of second-order serial correlation. ${ }^{1}$

To determine the moderating role of external governance on the impact of IC on MFIs' financial and social efficiency, the interaction term models are specified as follows:

$$
\begin{aligned}
& \mathrm{FINE}_{i t}=\beta_{0}+\beta_{1} \mathrm{WGI}_{i t}+\beta_{2} \mathrm{VAIC}_{i t}+\beta_{3}\left(\mathrm{WGI}_{i t} \times \mathrm{VAIC}_{i t}\right)+\sum_{i t}^{n} \beta_{4,5,6,7} \mathrm{Control}_{i t}+\beta_{8} \mathrm{CYR}+\epsilon_{i t} \\
& \mathrm{FINE}_{i t}=\beta_{0}+\beta_{1} \mathrm{WGI}_{i t}+\beta_{2} \mathrm{HCE}_{i t}+\beta_{3}\left(\mathrm{WGI}_{i t} \times \mathrm{HCE}_{i t}\right)+\sum_{i t}^{n} \beta_{4,5,6,7} \mathrm{Control}_{i t}+\beta_{8} \mathrm{CYR}+\epsilon_{i t}
\end{aligned}
$$

$$
\mathrm{FINE}_{i t}=\beta_{0}+\beta_{1} \mathrm{WGI}_{i t}+\beta_{2} \mathrm{SCE}_{i t}+\beta_{3}\left(\mathrm{WGI}_{i t} \times \mathrm{SCE}_{i t}\right)+\sum_{i t}^{n} \beta_{4,5,6,7} \operatorname{Control}_{i t}+\beta_{8} \mathrm{CYR}+\epsilon_{i t}
$$

$$
\mathrm{FINE}_{i t}=\beta_{0}+\beta_{1} \mathrm{WGI}_{i t}+\beta_{2} \mathrm{CEE}_{i t}+\beta_{3}\left(\mathrm{WGI}_{i t} \times \mathrm{CEE}_{i t}\right)+\sum_{i t}^{n} \beta_{4,5,6,7} \mathrm{Control}_{i t}+\beta_{8} \mathrm{CYR}+\epsilon_{i t}
$$

$$
\mathrm{SOCE}_{i t}=\beta_{0}+\beta_{1} \mathrm{WGI}_{i t}+\beta_{2} \mathrm{VAIC}_{i t}+\beta_{3}\left(\mathrm{WGI}_{i t} \times \mathrm{VAIC}_{i t}\right)+\sum_{i t}^{n} \beta_{4,5,6,7} \operatorname{Control}_{i t}+\beta_{8} \mathrm{CYR}+\epsilon_{i t}
$$

$$
\mathrm{SOCE}_{i t}=\beta_{0}+\beta_{1} \mathrm{WGI}_{i t}+\beta_{2} \mathrm{HCE}_{i t}+\beta_{3}\left(\mathrm{WGI}_{i t} \times \mathrm{HCE}_{i t}\right)+\sum_{i t}^{n} \beta_{4,5,6,7} \mathrm{Control}_{i t}+\beta_{8} \mathrm{CYR}+\epsilon_{i t}
$$

$$
\mathrm{SOCE}_{i t}=\beta_{0}+\beta_{1} \mathrm{WGI}_{i t}+\beta_{2} \mathrm{SCE}_{i t}+\beta_{3}\left(\mathrm{WGI}_{i t} \times \mathrm{SCE}_{i t}\right)+\sum_{i t}^{n} \beta_{4,5,6,7} \mathrm{Control}_{i t}+\beta_{8} \mathrm{CYR}+\epsilon_{i t}
$$

\footnotetext{
1 We thank the anonymous reviewer for this comment. Since the GMM estimator can account for the functional form of the model and omitted variable bias (see Baltagi, 2012; Roodman, 2009), it is not necessary to conduct the Ramsey RESET (Regression Equation Specification Error Test) to check for the functional form and omitted variable bias. The dynamic GMM counterpart of model 1 with lagged dependent variable is specified as follows:
}

$$
\mathrm{FINE}_{i t}=\beta_{0}+\beta_{1} \mathrm{FINE}_{i t-1}+\beta_{2} \mathrm{VAIC}_{i t}+\beta_{3} \mathrm{Size}+\beta_{4} \mathrm{WGI}+\beta_{5} \mathrm{INF}+\beta_{6} \mathrm{GDP}+\beta_{7} \mathrm{CY}+\epsilon_{i t}
$$


Table 2 Descriptive statistics

\begin{tabular}{llcccc}
\hline Variables & Observations & Mean & Minimum & Maximum & Standard deviation \\
\hline FINE & 1873 & 0.825 & 0.387 & 1 & 0.148 \\
SOCE & 1873 & 0.516 & 0.114 & 1 & 0.278 \\
VAIC & 1873 & 2.507 & 1.484 & 4.599 & 0.621 \\
HCE & 1873 & 3.493 & 1.829 & 8.678 & 1.016 \\
CEE & 1873 & 11.253 & 0.838 & 94.939 & 14.336 \\
SCE & 1873 & 0.696 & 0.453 & 0.902 & 0.072 \\
SIZE & 1873 & 17.043 & 12.327 & 21.282 & 1.984 \\
WGI & 1873 & -0.582 & -1.569 & 0.185 & 0.332 \\
INF & 1873 & 4.773 & -0.848 & 17.455 & 3.551 \\
GDP & 1873 & 3.265 & -4.168 & 9.826 & 2.664 \\
\hline
\end{tabular}

FINE financial efficiency, SOCE social efficiency, VAIC value-added intellectual capital, CEE value added by capital employed, HCE value added by human capital, SCE structural capital, WGI world governance indicators, SIZE assets, GDP GDP per capita growth

$$
\mathrm{SOCE}_{i t}=\beta_{0}+\beta_{1} \mathrm{WGI}_{i t}+\beta_{2} \mathrm{CEE}_{i t}+\beta_{3}\left(\mathrm{WGI}_{i t} \times \mathrm{CEE}_{i t}\right)+\sum_{i t}^{n} \beta_{4,5,6,7} \mathrm{Control}_{i t}+\beta_{8} \mathrm{CYR}+\epsilon_{i t}
$$

where $\mathrm{WGI}_{i t} \times \mathrm{VAIC}_{i t}$ represents interaction term between external governance and value-added intellectual capital, $\mathrm{WGI}_{i t} \times \mathrm{HCE}_{i t}$ represents interaction term between external governance and human capita, $\mathrm{WGI}_{i t} \times \mathrm{SCE}_{i t}$ represents interaction term between external governance and structural capital, and $\mathrm{WGI}_{i t} \times \mathrm{CEE}_{\text {it }}$ represents interaction term between external governance and value added by capital employed.

\section{Findings and Discussions}

The findings of this study are separated into two sections. The first part presents the financial and social efficiency score of MFIs using the Data Envelopment Analysis approach. The second part presents the effect of intellectual capital and its components on MFIs' efficiency. The descriptive statistics presented in Table 2 indicate that the study has 1873 observations. It shows wide variations among the variables in the study. For instance, the mean value of financial efficiency is 0.825 while the mean value of social efficiency is 0.516 , suggesting that MFIs' financial efficiency is greater than MFIs' social efficiency during the period. The mean value of intellectual capital is 2.507, while its components, namely, human capital, capital employed, and structural capital, have mean values of $3.493,11.253$, and 0.696, respectively. The corresponding standard deviations of the variables are 0.148 , $0.278,0.621,1.016,14.336$, and 0.72 , demonstrating that the data points are quite spread out around the means. It is important to note that capital employed has the highest mean and standard deviation among all the variables.

The correlation analysis reported in Table 3 shows that all the variables have positive and significant relationship with financial efficiency except GDP that has 


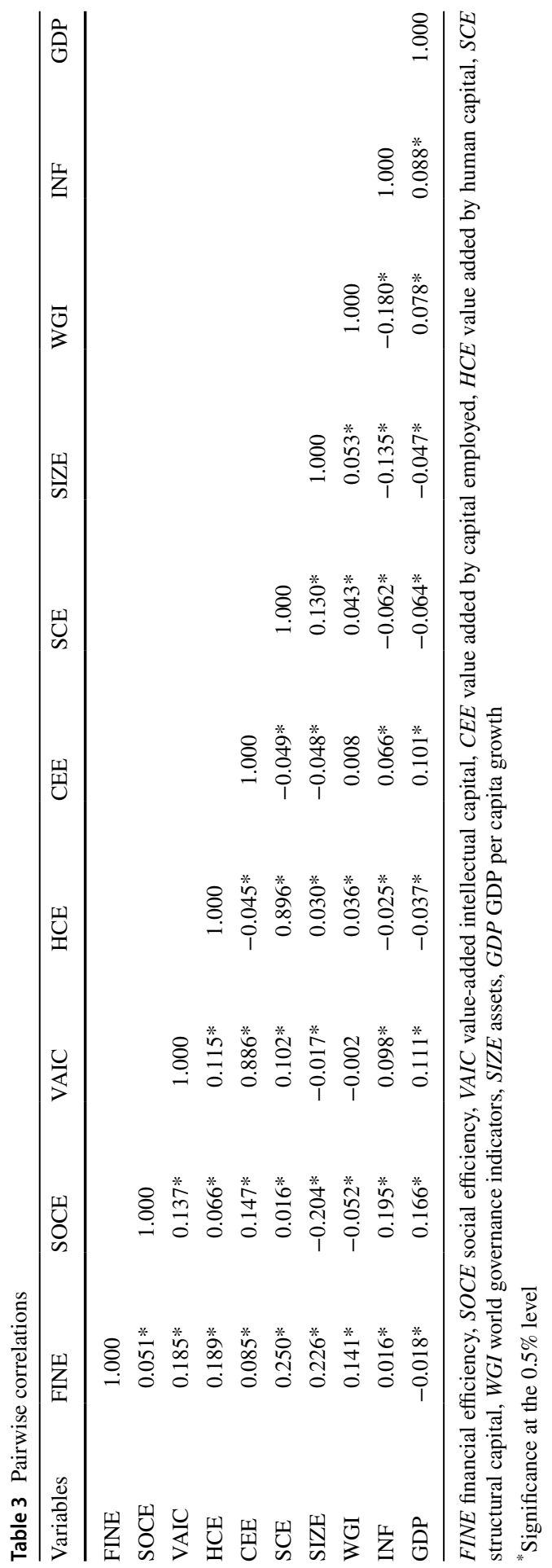


a negative correlation. Similarly, all the variables have positive and significant correlation with social efficiency except size of MFIs and WGI. However, the size of the correlation coefficients between the variables and MFIs' efficiency (financial and social efficiency) are small. Besides, the correlation analysis also shows the relationship between the other variables in the model. Correlation analysis is widely used to detect multicollinearity among variables. Kennedy (2008) suggested that the correlation coefficient should be within 0.8 . Table 3 reveals that the correlation coefficients are within an acceptable range. Hence, there is no multicollinearity among the variables in the models.

\section{First-Stage Efficiency Estimate}

The result of financial and social outreach efficiency on different aspects gives some valuable insight. Table 4 demonstrates that the average financial efficiency score for global MFIs is 0.823 , implying that MFIs are $82 \%$ financially efficient. The regional picture shows that MFIs are 74 to $90 \%$ financially efficient. These findings indicate that MFIs are still lagging in terms of achieving full efficiency. Access use of inputs is the cause of inefficiency as financial efficiency is analyzed with the input-oriented model. Thus, MFIs need to employ their inputs wisely to be fully efficient. Conversely, the social efficiency score globally is 0.516 , suggesting that MFIs are $51 \%$ efficient to achieve social outreach. The result reveals that MFIs are more financially efficient compared to social efficiency. The output-oriented model for social efficiency shows that inputs are less deployed for social outreach than concentrated on financial sustainability. These findings further indicate that MFIs need to efficiently manage their inputs for their better outreach goal and financial sustainability. For example, operational expenses should be reduced to reach their goals. Digital loan payment and collection processes (e.g., mobile banking and e-wallet system) can be introduced by inefficient MFIs.

Table 4 Global and regional efficiency score

\begin{tabular}{llll}
\hline Global and regional score & Observation & Financial efficiency & Social efficiency \\
\hline All sample & 1873 & 0.823 & 0.516 \\
Across region & & & \\
South Asia & 325 & 0.802 & 0.747 \\
East Asia and Pacific & 399 & 0.804 & 0.518 \\
Eastern Europe and Central Asia & 166 & 0.889 & 0.369 \\
Latin America and Caribbean & 564 & 0.900 & 0.374 \\
Middle East and North Africa & 15 & 0.770 & 0.380 \\
Africa & 404 & 0.740 & 0.589 \\
\hline
\end{tabular}

Financial efficiency used an input-oriented model and social efficiency used an output-oriented model 


\section{Second-Stage Regression Analysis}

The second stage results are presented in Tables 5, 6, and 7 with Truncated, Tobit, and GMM models. The result shows that value-added intellectual capital (VAIC) has a positive and significant coefficient on financial efficiency (as shown in Table 5). Hence, the proposed hypothesis is accepted. Moreover, the impact of intellectual capital on MFIs' social outreach efficiency is also evident by positive and significant coefficient (as shown in Table 6). Hence, the hypothesis of the effect of intellectual capital on social outreach efficiency is accepted. This finding suggests that MFIs with higher intellectual capital are more financially and socially efficient. This efficiency ultimately helps them to achieve self-sustainability and social outreach goals. These findings are consistent with the study conducted by Hashim et al.

Table 5 Regression result for financial efficiency

\begin{tabular}{|c|c|c|c|c|c|c|c|c|}
\hline & \multicolumn{4}{|c|}{ Truncated regression } & \multicolumn{4}{|c|}{ Tobit regression } \\
\hline & Model 1 & Model 2 & Model 3 & Mode 4 & Model 1 & Model 2 & Model 3 & Model 4 \\
\hline \multirow[t]{2}{*}{ VAIC } & $0.072 * * *$ & & & & $0.054 * * *$ & & & \\
\hline & {$[0.012]$} & & & & {$[0.007]$} & & & \\
\hline \multirow[t]{2}{*}{ HCE } & & $0.034 * * *$ & & & & $0.036^{* * *}$ & & \\
\hline & & {$[0.008]$} & & & & {$[0.005]$} & & \\
\hline \multirow[t]{2}{*}{ CEE } & & & $0.002 * * *$ & & & & $0.001 * * *$ & \\
\hline & & & {$[0.001]$} & & & & {$[0.000]$} & \\
\hline \multirow[t]{2}{*}{ SCE } & & & & $0.574 * * *$ & & & & $0.569 * * *$ \\
\hline & & & & {$[0.090]$} & & & & {$[0.061]$} \\
\hline \multirow[t]{2}{*}{ SIZE } & $0.029 * * *$ & $0.029 * * *$ & $0.030 * * *$ & $0.026 * * *$ & $0.020 * * *$ & $0.019 * * *$ & $0.020 * * *$ & $0.017 * * *$ \\
\hline & {$[0.003]$} & {$[0.003]$} & {$[0.003]$} & {$[0.003]$} & {$[0.002]$} & {$[0.002]$} & {$[0.002]$} & {$[0.002]$} \\
\hline \multirow[t]{2}{*}{ WGI } & $0.106 * * *$ & $0.106 * * *$ & $0.106^{* * *}$ & $0.104 * * *$ & $0.082 * * *$ & $0.079 * * *$ & $0.081 * * *$ & $0.078 * * *$ \\
\hline & [0.019] & [0.019] & {$[0.020]$} & [0.019] & {$[0.013]$} & {$[0.013]$} & {$[0.013]$} & {$[0.012]$} \\
\hline \multirow[t]{2}{*}{ INF } & $0.003^{*}$ & $0.005^{* * *}$ & $0.004 * *$ & $0.005^{* * *}$ & $0.003^{* *}$ & $0.004 * * *$ & $0.004 * * *$ & $0.004 * * *$ \\
\hline & {$[0.002]$} & {$[0.002]$} & {$[0.002]$} & {$[0.002]$} & {$[0.001]$} & {$[0.001]$} & {$[0.001]$} & {$[0.001]$} \\
\hline \multirow[t]{2}{*}{ GDP } & -0.002 & 0.000 & -0.001 & 0.001 & $-0.003^{* *}$ & -0.001 & $-0.003^{*}$ & -0.001 \\
\hline & {$[0.002]$} & {$[0.002]$} & {$[0.002]$} & {$[0.002]$} & {$[0.001]$} & {$[0.001]$} & {$[0.001]$} & {$[0.001]$} \\
\hline \multirow[t]{2}{*}{ CYR } & $-0.000 * * *$ & $-0.000 * * *$ & $-0.000^{* * *} *$ & $-0.000^{* * * *}$ & $-0.000 * * *$ & $-0.000 * * *$ & $-0.000 * * *$ & $-0.000 * * *$ \\
\hline & {$[0.000]$} & {$[0.000]$} & {$[0.000]$} & {$[0.000]$} & {$[0.000]$} & {$[0.000]$} & {$[0.000]$} & {$[0.000]$} \\
\hline \multirow[t]{2}{*}{ Constant } & $0.279 * * *$ & $0.339 * * *$ & $0.419 * * *$ & 0.103 & $0.427 * * *$ & $0.435 * * *$ & $0.535 * * *$ & $0.199 * * *$ \\
\hline & [0.068] & [0.068] & {$[0.066]$} & {$[0.082]$} & {$[0.046]$} & {$[0.045]$} & [0.044] & {$[0.057]$} \\
\hline $\begin{array}{l}\text { Observa- } \\
\text { tions }\end{array}$ & 1582 & 1582 & 1582 & 1582 & 1873 & 1873 & 1873 & 1873 \\
\hline $\begin{array}{l}\text { Wald } \mathrm{chi}^{2} \\
\text { (6) }\end{array}$ & 174.42 & 147.69 & 136.63 & 176.96 & & & & \\
\hline Prob $>\mathrm{chi}^{2}$ & 0.0000 & 0.0000 & 0.0000 & 0.0000 & & & & \\
\hline$F(6,1867)$ & & & & & 35.06 & 34.28 & 25.04 & 38.72 \\
\hline Prob $>F$ & & & & & 0.0000 & 0.0000 & 0.0000 & 0.0000 \\
\hline
\end{tabular}

Number of observation truncated for model 1 to 4 in Truncated regression is 291 and observation censored for Tobit regression in left 0 and in right 291 for models 1 to 4 . Standard errors in brackets: $* p<0.1 ; * * p<0.05 ; * * * p<0.01$ 
Table 6 Regression result for social efficiency

\begin{tabular}{|c|c|c|c|c|c|c|c|c|}
\hline & \multicolumn{4}{|c|}{ Truncated regression } & \multicolumn{4}{|c|}{ Tobit regression } \\
\hline & Model 5 & Model 6 & Model 7 & Model 8 & Model 5 & Model 6 & Model 7 & Model 8 \\
\hline \multirow[t]{2}{*}{ VAIC } & $0.039 * * *$ & & & & $0.056^{* * * *}$ & & & \\
\hline & {$[0.012]$} & & & & {$[0.012]$} & & & \\
\hline \multirow[t]{2}{*}{ HCE } & & 0.003 & & & & $0.031 * * *$ & & \\
\hline & & {$[0.007]$} & & & & {$[0.008]$} & & \\
\hline \multirow[t]{2}{*}{ CEE } & & & $0.002 * * *$ & & & & $0.003 * * *$ & \\
\hline & & & {$[0.001]$} & & & & {$[0.001]$} & \\
\hline \multirow[t]{2}{*}{ SCE } & & & & -0.002 & & & & $0.323 * * *$ \\
\hline & & & & {$[0.100]$} & & & & {$[0.107]$} \\
\hline \multirow[t]{2}{*}{ SIZE } & $-0.019 * * *$ & $-0.019 * * *$ & $-0.018 * * *$ & $-0.019 * * *$ & $-0.031 * * *$ & $-0.031 * * *$ & $-0.030 * * *$ & $-0.032 * * *$ \\
\hline & {$[0.004]$} & {$[0.004]$} & {$[0.004]$} & {$[0.004]$} & {$[0.004]$} & {$[0.004]$} & {$[0.004]$} & {$[0.004]$} \\
\hline \multirow[t]{2}{*}{ WGI } & $-0.052 * *$ & $-0.051 * *$ & $-0.053 * *$ & $-0.051 * *$ & -0.009 & -0.011 & -0.010 & -0.010 \\
\hline & {$[0.021]$} & {$[0.021]$} & {$[0.021]$} & {$[0.021]$} & {$[0.022]$} & {$[0.022]$} & {$[0.022]$} & {$[0.022]$} \\
\hline \multirow[t]{2}{*}{ INF } & $0.011 * * *$ & $0.012 * * *$ & $0.011 * * *$ & $0.012 * * *$ & $0.013 * * *$ & $0.014 * * *$ & $0.013 * * *$ & $0.014 * * *$ \\
\hline & {$[0.002]$} & {$[0.002]$} & {$[0.002]$} & {$[0.002]$} & {$[0.002]$} & {$[0.002]$} & {$[0.002]$} & {$[0.002]$} \\
\hline \multirow[t]{2}{*}{ GDP } & $0.015^{* * *}$ & $0.016^{* * *}$ & $0.015^{* * *}$ & $0.016 * * *$ & $0.015 * * *$ & $0.017 * * *$ & $0.015 * * *$ & $0.017 * * *$ \\
\hline & {$[0.002]$} & {$[0.002]$} & {$[0.002]$} & {$[0.002]$} & {$[0.003]$} & [0.003] & [0.003] & {$[0.003]$} \\
\hline \multirow[t]{2}{*}{ CYR } & $-0.000 * * *$ & $-0.000 * * *$ & $-0.000^{* * *}$ & $-0.000^{* * *}$ & $-0.000 * * *$ & $-0.000 * * *$ & $-0.000 * * *$ & $-0.000 * * *$ \\
\hline & {$[0.000]$} & {$[0.000]$} & {$[0.000]$} & {$[0.000]$} & {$[0.000]$} & {$[0.000]$} & {$[0.000]$} & {$[0.000]$} \\
\hline \multirow[t]{2}{*}{ Constant } & $0.558 * * *$ & $0.637 * * *$ & $0.617 * * *$ & $0.648 * * *$ & $0.843 * * *$ & $0.875 * * *$ & $0.939 * * *$ & $0.773 * * *$ \\
\hline & [0.080] & [0.077] & {$[0.075]$} & [0.094] & [0.085] & [0.083] & [0.081] & [0.101] \\
\hline $\begin{array}{l}\text { Observa- } \\
\text { tions }\end{array}$ & 1618 & 1618 & 1618 & 1618 & 1873 & 1873 & 1873 & 1873 \\
\hline $\begin{array}{l}\text { Wald } \text { chi }^{2} \\
\text { (6) }\end{array}$ & 150.13 & 139.50 & 152.91 & 139.77 & & & & \\
\hline Prob $>\mathrm{chi}^{2}$ & 0.0000 & 0.0000 & 0.0000 & 0.0000 & & & & \\
\hline$F(6,1867)$ & & & & & 34.52 & 32.39 & 34.99 & 31.98 \\
\hline Prob $>F$ & & & & & 0.0000 & 0.0000 & 0.0000 & 0.0000 \\
\hline
\end{tabular}

Number of observation truncated for model 1 to 4 in Truncated regression is 255 and observation censored for Tobit regression left 0 and right 255 for models 1 to 4 . Standard errors in brackets: * $p<0.1$; $* * p<0.05 ; * * * p<0.01$

(2018) in the microfinance area, and Adesina (2019), Vidyarthi and Tiwari (2019), and Soewarno and Tjahjadi (2020) in the banking sector. The findings also validate the IC theory for the microfinance industry. Furthermore, the positive and significant impact of intellectual capital on MFIs' financial and social efficiency is consistent with the RBV theory which emphasizes that intellectual capital is an essential and potential resource for a firm's better performance (Wernerfelt, 1984). Moreover, the theory emphasizes that this kind of resource empowers organizations and helps them implement strategies that improve their efficiency. Our study has succeeded in extending this notion to the microfinance industry.

Additionally, the analysis of individual components of the value-added intellectual capital shows that all three components (HCE, CEE, and SCE) have positive and significant impacts on financial efficiency. Hence, the hypotheses of the effect 
Table 7 Robustness checks using GMM estimator

\begin{tabular}{|c|c|c|c|c|c|c|c|c|}
\hline & Financial & efficiency & & & Social eff & ciency & & \\
\hline & Model 1 & Model 2 & Model 3 & Model 4 & Model 5 & Model 6 & Model 7 & Model 8 \\
\hline $\begin{array}{l}\text { Lagged } \\
\text { dependent } \\
\text { variable }\end{array}$ & $\begin{array}{l}0.438 * * * \\
{[0.167]}\end{array}$ & $\begin{array}{l}0.433 * * * \\
{[0.116]}\end{array}$ & $\begin{array}{l}0.774 * * * \\
{[0.164]}\end{array}$ & $\begin{array}{l}0.669 * * * \\
{[0.103]}\end{array}$ & $\begin{array}{l}0.411 * * * \\
{[0.154]}\end{array}$ & $\begin{array}{l}0.600 * * * \\
{[0.146]}\end{array}$ & $\begin{array}{l}0.629 * * * \\
{[0.183]}\end{array}$ & $\begin{array}{l}0.554 * * * \\
{[0.161]}\end{array}$ \\
\hline VAIC & $\begin{array}{l}0.049 * * \\
{[0.022]}\end{array}$ & & & & $\begin{array}{l}0.039^{*} \\
{[0.021]}\end{array}$ & & & \\
\hline $\mathrm{HCE}$ & & $\begin{array}{l}0.018 * * * \\
{[0.006]}\end{array}$ & & & & $\begin{array}{l}0.111^{*} \\
{[0.059]}\end{array}$ & & \\
\hline CEE & & & $\begin{array}{l}0.002 * \\
{[0.001]}\end{array}$ & & & & $\begin{array}{l}0.009^{* *} \\
{[0.004]}\end{array}$ & \\
\hline SCE & & & & $\begin{array}{l}0.304 * * * \\
{[0.115]}\end{array}$ & & & & $\begin{array}{l}1.238 * * \\
{[0.545]}\end{array}$ \\
\hline SIZE & $\begin{array}{l}0.019 * * \\
{[0.009]}\end{array}$ & $\begin{array}{l}0.008 \\
{[0.006]}\end{array}$ & $\begin{array}{l}0.016 \\
{[0.015]}\end{array}$ & $\begin{array}{l}0.020^{*} \\
{[0.011]}\end{array}$ & $\begin{array}{l}0.003 \\
{[0.011]}\end{array}$ & $\begin{array}{l}0.023 \\
{[0.018]}\end{array}$ & $\begin{array}{l}0.017 \\
{[0.015]}\end{array}$ & $\begin{array}{l}0.005 \\
{[0.011]}\end{array}$ \\
\hline WGI & $\begin{array}{l}-0.033 \\
{[0.104]}\end{array}$ & $\begin{array}{l}0.290 * * \\
{[0.128]}\end{array}$ & $\begin{array}{l}0.316^{* *} \\
{[0.142]}\end{array}$ & $\begin{array}{l}0.280^{* *} \\
{[0.132]}\end{array}$ & $\begin{array}{l}0.218 \\
{[0.192]}\end{array}$ & $\begin{array}{l}0.541 * * * \\
{[0.202]}\end{array}$ & $\begin{array}{l}0.618 * * * \\
{[0.152]}\end{array}$ & $\begin{array}{l}-0.095^{*} \\
{[0.050]}\end{array}$ \\
\hline INF & $\begin{array}{l}-0.006 \\
{[0.005]}\end{array}$ & $\begin{array}{l}0.001 \\
{[0.005]}\end{array}$ & $\begin{array}{l}0.002 \\
{[0.006]}\end{array}$ & $\begin{array}{l}0.001 \\
{[0.005]}\end{array}$ & $\begin{array}{l}-0.015^{*} \\
{[0.008]}\end{array}$ & $\begin{array}{l}-0.006 \\
{[0.012]}\end{array}$ & $\begin{array}{l}0.014 * * * \\
{[0.005]}\end{array}$ & $\begin{array}{l}-0.030 * * \\
{[0.012]}\end{array}$ \\
\hline GDP & $\begin{array}{l}0.017 \\
{[0.011]}\end{array}$ & $\begin{array}{l}-0.003 \\
{[0.004]}\end{array}$ & $\begin{array}{l}0.002 \\
{[0.004]}\end{array}$ & $\begin{array}{l}-0.006 \\
{[0.004]}\end{array}$ & $\begin{array}{l}0.031 * * * \\
{[0.010]}\end{array}$ & $\begin{array}{l}0.018 \\
{[0.011]}\end{array}$ & $\begin{array}{l}0.013 \\
{[0.009]}\end{array}$ & $\begin{array}{l}0.018^{*} \\
{[0.010]}\end{array}$ \\
\hline CYR & $\begin{array}{l}0.000^{*} \\
{[0.000]}\end{array}$ & $\begin{array}{l}-0.000 \\
{[0.000]}\end{array}$ & $\begin{array}{l}0.000 \\
{[0.000]}\end{array}$ & $\begin{array}{l}-0.000 * * \\
{[0.000]}\end{array}$ & $\begin{array}{l}-0.000 \\
{[0.000]}\end{array}$ & $\begin{array}{l}-0.000 \\
{[0.000]}\end{array}$ & $\begin{array}{l}-0.000 \\
{[0.000]}\end{array}$ & $\begin{array}{l}0.000 \\
{[0.000]}\end{array}$ \\
\hline Constant & $\begin{array}{l}-0.198 \\
{[0.241]}\end{array}$ & $\begin{array}{l}0.546 * * * \\
{[0.193]}\end{array}$ & $\begin{array}{l}0.032 \\
{[0.293]}\end{array}$ & $\begin{array}{l}0.139 \\
{[0.251]}\end{array}$ & $\begin{array}{l}0.285 \\
{[0.327]}\end{array}$ & $\begin{array}{l}-0.298 \\
{[0.347]}\end{array}$ & $\begin{array}{l}0.097 \\
{[0.352]}\end{array}$ & $\begin{array}{l}-0.741^{*} \\
{[0.378]}\end{array}$ \\
\hline Observations & 976 & 976 & 976 & 976 & 976 & 976 & 976 & 976 \\
\hline $\mathrm{AR}(1)$ & 0.000 & 0.000 & 0.000 & 0.000 & 0.011 & 0.000 & 0.007 & 0.001 \\
\hline $\mathrm{AR}(2)$ & 0.844 & 0.988 & 0.633 & 0.535 & 0.905 & 0.085 & 0.592 & 0.275 \\
\hline $\begin{array}{c}\text { Hansen test } \\
(p \text {-value })\end{array}$ & 0.053 & 0.053 & 0.066 & 0.056 & 0.061 & 0.054 & 0.058 & 0.061 \\
\hline $\begin{array}{l}\text { No. of instru- } \\
\text { ments }\end{array}$ & 24 & 31 & 33 & 35 & 41 & 40 & 42 & 42 \\
\hline $\begin{array}{l}\text { No. of } \\
\text { groups }\end{array}$ & 369 & 369 & 369 & 369 & 369 & 369 & 369 & 369 \\
\hline
\end{tabular}

of HCE, CEE, and SCE on MFIs' financial efficiency are accepted. These findings are inconsistent with Hashim et al. (2018) and Adesina (2019) who found that only capital employed and human capital are substantial for firm financial performance. On the other hand, the findings are consistent with $\mathrm{Xu}$ and Li (2019) and Vidyarthi and Tiwari (2019) who found that these components are the influential drivers for firms' financial performance. These findings suggest that MFIs with higher human capital, structural capital, and value-added capital employed are more efficient financially, which ultimately helps them to be self-sustainable. Moreover, the findings on 
social efficiency show that CEE is positive and significantly influences social outreach efficiency; the impacts of HCE and CEE are insignificant. This result is consistent with Hashim et al. (2018). Therefore, the insignificant result suggests that the use of excessive physical and human capital may adversely affect social outreach efficiency. Nevertheless, the robustness analysis used by Tobit and GMM (as shown in Table 7) shows that both HCE and CEE are positively and significantly influence MFI's social outreach efficiency.

The findings validate the theory of intellectual capital in the microfinance industry which argues that "once an organization becomes aligned and balanced with the three foundational components (human capital, structural capital, and capital employed) of intellectual capital, it can create the best possible financial value" (Edvinsson \& Malone, 1997). This statement is consistent with Stewart (1997) that an organization could bring success by managing intellectual capital properly. Moreover, the Resource-Based View (RBV) theory posits that business performance can be improved once the firm has precious resources (Wernerfelt, 1984). A combination of these resources (human capital, organizational capital, and physical capital) enables MFIs to gain a sustainable competitive advantage to increase their efficiency. The arguments and ruling of both theories support the positive and significant findings of this study in the microfinance industry and support the hypotheses. The study also agreed with previous studies (Amrizah \& Rashidah, 2013; Majumder, 2012; Vidyarthi \& Tiwari, 2019) that postulated that these resources could empower the organizations which can help them to implement strategies to improve institutional efficiency.

Hypotheses H3 and H4 (and the subsequent hypotheses H3a, H3b, H3c, H4a, $\mathrm{H} 4 \mathrm{~b}, \mathrm{H} 4 \mathrm{c}$ ) were formulated to answer the question of whether external governance moderates the relationship between the determinants (VAIC, HCE, SCE, and CEE) and MFI's financial and social efficiency. To test this hypothesis, a moderating variable was initially included in the equation to test its independent effect on the dependent variable. Secondly, the equation contains predictor variables. Interaction terms have been inserted into the equation in the third stage in order to measure the combined effect of the predictor variables and the moderator on the dependent variables. The term interaction was computed by the moderating variable multiplying the predictor variables.

The result reported in Table 8 shows that external governance moderates the relationship between intellectual capital and MFIs' financial efficiency. Thus, H3 is accepted. However, Table 9 indicates that external governance plays no significant moderating role in the relationships between intellectual capital and social outreach efficiency. The result implies that external governance does not strengthen the relationship between intellectual capital and social efficiency.

The subsequent analysis of the components of IC shows that external governance does not strengthen the relationship between the components and financial and social efficiency. Only the relationship between CEE and financial efficiency is strengthened by good governance. The possible explanation can be the prediction given by Hermes and Hudon (2018), where the authors came up with the vast literature evidence. The author mentioned that a well-developed institution could make operating a business more challenging. Specifically, an efficient 
Table 8 Result of the moderating effect of WGI on financial efficiency

\begin{tabular}{|c|c|c|c|c|c|c|c|c|}
\hline & \multicolumn{4}{|c|}{ Truncated regression } & \multicolumn{4}{|c|}{ Tobit regression } \\
\hline & Model 9 & Model 10 & Model 11 & Model 12 & Model 9 & Model 10 & Model 11 & Model 12 \\
\hline \multirow[t]{2}{*}{ WGI } & -0.144 & $0.176^{* *}$ & $0.068^{* *}$ & 0.186 & -0.069 & $0.114 * * *$ & $0.057 * * *$ & 0.145 \\
\hline & {$[0.089]$} & {$[0.076]$} & {$[0.026]$} & {$[0.165]$} & {$[0.057]$} & {$[0.042]$} & {$[0.017]$} & {$[0.116]$} \\
\hline \multirow[t]{2}{*}{ VAIC } & $0.137 * * *$ & & & & $0.089^{* * *}$ & & & \\
\hline & {$[0.026]$} & & & & {$[0.014]$} & & & \\
\hline \multirow[t]{2}{*}{ VAIC $\times$ WGI } & $0.104 * * *$ & & & & $0.060 * * *$ & & & \\
\hline & {$[0.037]$} & & & & {$[0.022]$} & & & \\
\hline \multirow[t]{2}{*}{ HCE } & & 0.021 & & & & $0.030 * * *$ & & \\
\hline & & {$[0.016]$} & & & & {$[0.008]$} & & \\
\hline \multirow[t]{2}{*}{ HCE $\times$ WGI } & & -0.021 & & & & -0.010 & & \\
\hline & & {$[0.022]$} & & & & {$[0.011]$} & & \\
\hline \multirow[t]{2}{*}{ CEE } & & & $0.004 * * *$ & & & & $0.002 * * *$ & \\
\hline & & & {$[0.001]$} & & & & {$[0.001]$} & \\
\hline \multirow[t]{2}{*}{$\mathrm{CEE} \times$ WGI } & & & $0.004 * *$ & & & & $0.002 * *$ & \\
\hline & & & {$[0.002]$} & & & & {$[0.001]$} & \\
\hline \multirow[t]{2}{*}{ SCE } & & & & $0.499 * * *$ & & & & $0.512 * * *$ \\
\hline & & & & {$[0.188]$} & & & & {$[0.116]$} \\
\hline \multirow[t]{2}{*}{ SCE $\times$ WGI } & & & & -0.121 & & & & -0.097 \\
\hline & & & & {$[0.241]$} & & & & {$[0.166]$} \\
\hline \multirow[t]{2}{*}{ SIZE } & $0.030^{* * *}$ & $0.029 * * *$ & $0.031 * * *$ & $0.026 * * *$ & $0.020 * * *$ & $0.019 * * *$ & $0.020 * * *$ & $0.017 * * *$ \\
\hline & {$[0.003]$} & {$[0.003]$} & {$[0.003]$} & {$[0.003]$} & {$[0.002]$} & {$[0.002]$} & {$[0.002]$} & {$[0.002]$} \\
\hline \multirow[t]{2}{*}{ INF } & $0.003^{*}$ & $0.005^{* * *}$ & $0.004 * *$ & $0.005^{* * *}$ & $0.003 * * *$ & $0.004 * * *$ & $0.004 * * *$ & $0.005^{* * *}$ \\
\hline & {$[0.002]$} & {$[0.002]$} & {$[0.002]$} & {$[0.002]$} & {$[0.001]$} & {$[0.001]$} & {$[0.001]$} & {$[0.001]$} \\
\hline \multirow[t]{2}{*}{ GDP } & -0.002 & 0.000 & -0.001 & 0.001 & $-0.003^{* *}$ & -0.001 & -0.002 & -0.001 \\
\hline & {$[0.002]$} & {$[0.002]$} & {$[0.002]$} & {$[0.002]$} & {$[0.001]$} & {$[0.001]$} & {$[0.001]$} & {$[0.001]$} \\
\hline \multirow[t]{2}{*}{ CYR } & $-0.000 * * *$ & $-0.000 * * *$ & $-0.000 * * *$ & $-0.000 * * *$ & $-0.000 * * *$ & $-0.000^{* * *}$ & $-0.000 * * *$ & $-0.000 * * *$ \\
\hline & {$[0.000]$} & {$[0.000]$} & {$[0.000]$} & {$[0.000]$} & {$[0.000]$} & {$[0.000]$} & {$[0.000]$} & {$[0.000]$} \\
\hline \multirow[t]{2}{*}{ Constant } & 0.122 & $0.381 * * *$ & $0.394 * * *$ & 0.153 & $0.338^{* * *}$ & $0.455^{* * *}$ & $0.519 * * *$ & $0.237 * * *$ \\
\hline & {$[0.088]$} & {$[0.085]$} & {$[0.066]$} & {$[0.140]$} & {$[0.056]$} & {$[0.051]$} & [0.044] & [0.089] \\
\hline Observations & 1582 & 1582 & 1582 & 1582 & 1873 & 1873 & 1873 & 1873 \\
\hline Wald $\operatorname{chi}^{2}(7)$ & 168.62 & 152.99 & 135.92 & 182.19 & & & & \\
\hline Prob $>\mathrm{chi}^{2}$ & 0.0000 & 0.0000 & 0.0000 & 0.0000 & & & & \\
\hline$F(7,1866)$ & & & & & 30.31 & 29.71 & 21.80 & 33.42 \\
\hline Prob $>F$ & & & & & 0.0000 & 0.0000 & 0.0000 & 0.0000 \\
\hline
\end{tabular}

Number of observation truncated for model 1 to 4 in Truncated regression is 255 and observation censored for Tobit regression left 0 and right 255 for models 1 to 4 . Standard errors in brackets: $* p<0.1$; $* * p<0.05 ; * * * p<0.01$

government can also be indicated by an excess number of laws and regulations, resulting in higher costs for smaller companies, lowering their demand for services. Sometimes, the regulations can make it difficult for small-size business to access government services without paying required charges. Thus, it influences them to bypass all sorts of expensive government regulations including tax payment obligation. Further, Churchill (2018) stated that governance quality is not 
Table 9 Result of the moderating effect of WGI on social efficiency

\begin{tabular}{|c|c|c|c|c|c|c|c|c|}
\hline & \multicolumn{4}{|c|}{ Truncated regression } & \multicolumn{4}{|c|}{ Tobit regression } \\
\hline & Model 13 & Model 14 & Model 15 & Model 16 & Model 13 & Model 14 & Model 15 & Model 16 \\
\hline \multirow[t]{2}{*}{ WGI } & $-0.151^{*}$ & 0.004 & $-0.072 * * *$ & -0.053 & -0.052 & 0.028 & -0.004 & -0.168 \\
\hline & {$[0.081]$} & {$[0.063]$} & {$[0.027]$} & {$[0.181]$} & [0.087] & {$[0.070]$} & {$[0.028]$} & {$[0.189]$} \\
\hline \multirow[t]{2}{*}{ VAIC } & $0.061 * * *$ & & & & $0.066^{* * *}$ & & & \\
\hline & {$[0.021]$} & & & & {$[0.023]$} & & & \\
\hline \multirow[t]{2}{*}{ VAIC $\times$ WGI } & 0.039 & & & & 0.017 & & & \\
\hline & {$[0.030]$} & & & & {$[0.033]$} & & & \\
\hline \multirow[t]{2}{*}{ HCE } & & -0.006 & & & & $0.025^{*}$ & & \\
\hline & & {$[0.012]$} & & & & {$[0.014]$} & & \\
\hline \multirow[t]{2}{*}{ HCE $\times$ WGI } & & -0.016 & & & & -0.011 & & \\
\hline & & {$[0.016]$} & & & & {$[0.019]$} & & \\
\hline \multirow[t]{2}{*}{ CEE } & & & $0.003 * * *$ & & & & $0.003^{* *}$ & \\
\hline & & & {$[0.001]$} & & & & {$[0.001]$} & \\
\hline \multirow[t]{2}{*}{$\mathrm{CEE} \times$ WGI } & & & 0.002 & & & & -0.000 & \\
\hline & & & {$[0.001]$} & & & & {$[0.001]$} & \\
\hline \multirow[t]{2}{*}{ SCE } & & & & -0.001 & & & & $0.455^{* *}$ \\
\hline & & & & {$[0.176]$} & & & & {$[0.185]$} \\
\hline \multirow[t]{2}{*}{ SCE $\times$ WGI } & & & & 0.003 & & & & 0.227 \\
\hline & & & & {$[0.260]$} & & & & {$[0.273]$} \\
\hline \multirow[t]{2}{*}{ SIZE } & $-0.018^{* * *}$ & $-0.019 * * *$ & $-0.018 * * *$ & $-0.019 * * *$ & $-0.031^{* * *}$ & -0.031 *** & $-0.030^{* * *}$ & $-0.032 * * *$ \\
\hline & {$[0.004]$} & {$[0.004]$} & {$[0.004]$} & {$[0.004]$} & {$[0.004]$} & {$[0.004]$} & {$[0.004]$} & {$[0.004]$} \\
\hline \multirow[t]{2}{*}{ INF } & $0.011 * * *$ & $0.012 * * *$ & $0.011 * * *$ & $0.012 * * *$ & $0.013 * * *$ & $0.014 * * *$ & $0.013 * * *$ & $0.014 * * *$ \\
\hline & {$[0.002]$} & {$[0.002]$} & {$[0.002]$} & {$[0.002]$} & {$[0.002]$} & {$[0.002]$} & {$[0.002]$} & {$[0.002]$} \\
\hline \multirow[t]{2}{*}{ GDP } & $0.015^{* * *}$ & $0.016^{* * *}$ & $0.015 * * *$ & $0.016^{* * * *}$ & $0.015^{* * *}$ & $0.017 * * *$ & $0.015^{* * *}$ & $0.017 * * *$ \\
\hline & {$[0.002]$} & {$[0.002]$} & {$[0.002]$} & {$[0.002]$} & {$[0.003]$} & {$[0.003]$} & {$[0.003]$} & {$[0.003]$} \\
\hline \multirow[t]{2}{*}{ CYR } & $-0.000 * * *$ & $-0.000 * * *$ & $-0.000 * * *$ & $-0.000 * * *$ & $-0.000 * * *$ & $-0.000 * * *$ & $-0.000 * * *$ & $-0.000 * * *$ \\
\hline & {$[0.000]$} & {$[0.000]$} & {$[0.000]$} & {$[0.000]$} & {$[0.000]$} & {$[0.000]$} & {$[0.000]$} & {$[0.000]$} \\
\hline \multirow[t]{2}{*}{ Constant } & $0.499 * * *$ & $0.668^{* * *}$ & $0.602 * * *$ & $0.647 * * *$ & $0.818^{* * *}$ & $0.896 * * *$ & $0.943 * * *$ & $0.684 * * *$ \\
\hline & {$[0.095]$} & {$[0.083]$} & {$[0.077]$} & [0.134] & {$[0.100]$} & [0.092] & {$[0.083]$} & [0.144] \\
\hline Observations & 1618 & 1618 & 1618 & 1618 & 1873 & 1873 & 1873 & 1873 \\
\hline Wald $\operatorname{chi}^{2}(7)$ & 153.46 & 140.47 & 156.85 & 139.86 & & & & \\
\hline Prob $>\mathrm{chi}^{2}$ & 0.0000 & 0.0000 & 0.0000 & 0.0000 & & & & \\
\hline$F(7,1866)$ & & & & & 29.63 & 27.91 & 30.08 & 27.61 \\
\hline Prob $>F$ & & & & & 0.0000 & 0.0000 & 0.0000 & 0.0000 \\
\hline
\end{tabular}

Number of observation truncated for model 1 to 4 in Truncated regression is 255 and observation censored for Tobit regression left 0 and right 255 for models 1 to 4 . Standard errors in brackets: ${ }^{*} p<0.1$; $* * p<0.05 ; * * * p<0.01$

conducive for MFIs' social outreach. This argument again supports Barry and Tacneng (2014) who found that weak governance favors institutions to provide loans to the insiders based on relationship. However, the findings of the current study corroborate these arguments.

Therefore, another possible explanation is that the world governance indicators' data demonstrate that most of the countries score below 2.00 out of the highest 
standard of 2.50. Specifically, the highest score shown in the descriptive statistics is 1.81 out of 2.5 . Furthermore, many countries performed a negative score. Overall, this low governance score can be the reason for the tenuous results.

As for the control variables included in the model, the results show that the size of MFIs is positive with financial efficiency, consistent with Bibi et al. (2018) but negative with social efficiency. This result implies that large firms can use their resources differently which enhance their financial efficiency. However, for social outreach efficiency, the firms' size does not play a significant role as MFIs run and serve with their social orientation objective. Macroeconomic factors, inflation, and GDP included in the study as MFIs are an integral part of the economy. For example, overall expenses are supposed to increase due to inflation. However, this study found a reverse result as it shows positive with both financial and social efficiency. The findings are consistent with Mia (2017) who reported similar results in the microfinance industry. GDP growth shows the progress of the overall economy and it is expected to have a positive effect. Therefore, this study found GDP growth positive with social efficiency. It implies that if the country's economy improves, it positively affects people. As a result, the deserved people can maintain their financial repayment of loans which helps MFIs to be efficient (Mia \& Soltane, 2016). Therefore, GDP growth exhibits a reverse result with financial efficiency which is consistent with Bibi et al. (2018). The author opined that when GDP increases, MFIs' efficiency declines. WGI has a positive impact on financial efficiency but negative with social efficiency. This finding is consistent with Mia (2017) and Müller and Uhde (2013) who reported similar empirical outcomes. This study fixed the country and year effect to control the country heterogeneity and the coefficient is insignificant.

\section{Implications and Recommendations}

Financial sustainability and social outreach efficiency are the twofold bottom lines of microfinance institutions. To achieve these goals, MFIs deploy their inputs. The findings of this study demonstrate that MFIs are not fully efficient in achieving the goals. It implies that some over-employment and under-employment of input and output combination exist, which cause the inefficiency. Furthermore, a comparison of two MFI's goals indicates that MFIs focus more on their financial efficiency than social efficiency. The somewhat lower financial efficiency and the intermediate social efficiency level of MFIs suggest that management should revise their input use policy in their operations. Effective use of available resources can enhance their sustainability and outreach. Therefore, due to the recent Covid-19 pandemic, many people will go under the poverty line and face unemployment situation globally (Zheng \& Zhang, 2021). Thus, this condition requires more financial assistance to recover their status. As a social mission-oriented institution, MFIs can significantly increase their efforts by providing collateral-free loans and other social supports to the deserved people. The international donor community and agencies could extend their hands to MFIs to serve the deserved people.

The second-stage findings establish that intellectual capital positively contributes to efficient MFIs. The three components of the IC are recognized as noteworthy for 
MFIs' growth. The findings validate the theory of intellectual capital in the microfinance industry that MFIs can successfully create value using the IC. Previously, traditional banking and other industries have identified the importance of IC regarding the literature. Therefore, this study emphasizes the importance of IC for the microfinance industry. Hence, this study strongly suggests that industry-related top management should focus more on these IC elements. More emphasis on intellectual capital will help them to optimize their poverty alleviation and sustainability goals. Subsequently, the positive results on structural capital, human capital, and capital employed imply that MFIs' top management should properly utilize their human resources, physical assets, and intellectual properties for better outreach. Government and related stakeholders and agencies can support MFIs to provide better staff training.

Furthermore, the result of governance suggests that good governance is needed for financial efficiency. Therefore, MFIs can achieve their social outreach goal if essential capital is appropriately utilized in their operations. Therefore, this study recommends that government and policymakers can help the microfinance industry with their corruption-free administration and other acceptable governance practices without imposing complex rules and regulations. These practices will ultimately help the countries reduce their poverty and their people will be able to increase their socio-economic well-being by receiving the services and benefits from the microfinance industry.

\section{Conclusion}

Intellectual capital and its components are the most significant determinants of firm's efficiency. To address this objective, this study uses data from 661 microfinance institutions from 86 countries. A two-stage analysis method is utilized in this study. Non-parametric DEA within the production approach is used to assess the financial and social efficiency of MFIs. The average financial efficiency score for global MFIs is 0.823 . The regional picture is also not much different though Latin America and the Caribbean, Europe, and Central Asia and South Asia demonstrate relatively high financial efficiency. However, this score implies that MFIs are still slightly lagging behind their financial sustainability. The average social efficiency scores globally and regionally are aligned with previous empirical evidence and it is below 60\% except for South Asia which is $74 \%$. This intermediate efficiency level implies that further managerial efforts are needed to enhance the MFIs' efficiency.

In the second stage, to find the variation in MFIs' efficiency, this study includes intellectual capital and its three components as possible key determinants. A Truncated regression technique was applied as baseline models to examine the impact of these determinants on efficiency. To ensure consistency and to avoid biasedness, the Tobit model and GMM were also employed. The findings show that intellectual capital is a positive and significant determinant of MFIs' financial and social efficiency. Consequently, the three components of intellectual capital (e.g., capital employed, human capital, and structural capital) have positive and significant impacts on the financial efficiency of MFIs. Therefore, these components also influence social 
efficiency. Furthermore, this study tested the moderating role of external governance on the relationship between IC and MFIs' efficiency. The findings show that good governance is a significant determinant of MFIs' financial stability and sustainability. Good governance has a positive moderating role on the impact of IC on financial efficiency albeit it has no significant moderating role on the impact of IC on social outreach efficiency.

Despite the useful findings of this study, there are some limitations. This study could not differentiate between MFIs such as bank MFIs, NGO and non-NGO, and regulated and non-regulated MFIs. Hence, it is recommended that future research should consider these differences. Although this study estimated microfinance efficiency with two important dimensions (i.e., financial and social outreach efficiency), allocative efficiency was not considered. But this type of economic efficiency will give a more holistic picture of the microfinance industry. Hence, future research should consider allocative efficiency. Although this study enhanced the existing literature by incorporating WGI as external governance factors, future studies should extend this analysis by incorporating other country context variables.

Availability of Data and Material Yes, data are available. The authors can provide upon request.

\section{Declarations}

Conflict of Interest The authors declare no competing interests.

\section{References}

Adesina, K. S. (2019). Bank technical, allocative and cost efficiencies in Africa: The influence of intellectual capital. The North American Journal of Economics and Finance, 48, 419-433.

Adnan, N. S., Kamaluddi, A., \& Kasim, N. (2013). Intellectual capital in religious organisations: Malaysian Zakat Institutions perspective. Middle-East Journal of Scientific Research, 16(3), 368-377.

Adusei, M. (2019). Board gender diversity and the technical efficiency of microfinance institutions: Does size matter? International Review of Economics \& Finance, 64, 393-411.

Ahamad, S., Al-jaifi, H. A., \& Mostafiz, M. I. (2020). Conceptualizing recourses as antecedents to the economic performance of family-based microenterprise-The moderating role of competencies. Journal of Family Business Management. Early view version.

Ahamad, S., Bakar, R., \& Lubis, Z. (2016). Islamic microfinance and its impacts on borrowers: A systematic review from 1995-2015. Mediterranean Journal of Social Sciences, 7(6), 113.

Akçay, A. E., Ertek, G., \& Büyüközkan, G. (2012). Analyzing the solutions of DEA through information visualization and data mining techniques: Smart DEA framework. Expert Systems with Applications, 39(9), 7763-7775.

Al-Shami, S. S. A., Majid, I. B. A., Rashid, N. A., \& Hamid, M. S. R. B. A. (2013). Conceptual framework: The role of microfinance on the wellbeing of poor people cases studies from Malaysia and Yemen. Asian Social Science, 10(1), 230-242.

Anku-Tsede, O. (2014). Microfinance intermediation: Regulation of financial NGOs in Ghana. International Journal of Law and Management, 56(4), 274-301.

Arellano, M., \& Bover, O. (1995). Another look at the instrumental variable estimation of error-components models. Journal of Econometrics, 68(1), 29-51.

Ashta, A., \& Fall, N. S. (2012). Institutional analysis to understand the growth of microfinance institutions in West African economic and monetary union. Corporate Governance, 12(4), 441-459. 
Ault, J., \& Spicer, A. (2014). The institutional context of poverty: State fragility as a predictor of cross-national variation in commercial microfinance lending. Strategic Management Journal, 35, 1818-1838.

Babu-Muneer, M., \& Kulshreshtha, P. (2017). Efficiency of Indian microfinance institutions. The Indian Economic Journal, 60(4), 81-101.

Bakker, A., Schaveling, J., \& Nijhof, A. (2014). Governance and microfinance institutions. Corporate Governance, 14(5), 637-652.

Baltagi, B. H. (2012). Econometric analysis of panel data (4th ed.). John Wiley and Sons Ltd.

Barney, J. (1991). Firm resources and sustained competitive advantage. Journal of Management, 17(1), 99-120.

Baron, A. (2011). Measuring human capital. Strategic HR Review, 10(2), 30-35.

Barry, T. A., \& Tacneng, R. (2014). The impact of governance and institutional quality on MFI outreach and financial performance in sub-Saharan Africa. World Development, 58, 1-20.

Bassem, B. S. (2008). Efficiency of microfinance institutions in the Mediterranean: An application of DEA. Transition Studies Review, 15(2), 343-354.

Bayraktaroglu, A. E., Calisir, F., \& Baskak, M. (2019). Intellectual capital and firm performance: An extended VAIC model. Journal of Intellectual Capital, 20(3), 406-425.

Bibi, U., Balli, H. O., Matthews, C. D., \& Tripe, D. W. (2018). Impact of gender and governance on microfinance efficiency. Journal of International Financial Markets, Institutions and Money, 53, 307-319.

Blundell, R., \& Bond, S. (1998). Initial conditions and moment restrictions in dynamic panel data models. Journal of Econometrics, 87(1), 115-143.

Boehe, D. M., \& Cruz, L. B. (2013). Gender and microfinance performance: Why does the institutional context matter? World Development, 47, 121-135.

Bontis, N., Keow, W. C. C., \& Richardson, S. (2000). Intellectual capital and business performance in Malaysian industries. Journal of Intellectual Capital, 1(1), 85-100.

Brooking, A. (1996). Intellectual Capital-Core asset for the third millennium enterprise. International Thomson Business Press. New York. Carpenter (Eds.), Handbook of Marketing Strategy (pp. 440456). Cheltenham, UK: Edward Elgar.

Churchill, S. A. (2018). The macroeconomy and microfinance outreach: A panel data analysis. Applied Economics, 51(21), 2266-2274.

Cooper, W. W., Seiford, L. M., \& Zhu, J. (2011). Data envelopment analysis: History, models, and interpretations. In Handbook on data envelopment analysis (pp. 1-39). Springer, Boston, MA.

Edvinsson, L., \& Malone, M. S. (1997). Intellectual capital: The proven way to establish your company's real value by finding its hidden brainpower. Piatkus Books, New Ed edition (May 28, 1998).

Emeni, F. (2008). Microfinance institutions in Nigeria: Problems and prospects. Journal of Financial Management and Analysis, 21(1), 69-76.

Fall, F., Akim, A. M., \& Wassongma, H. (2018). DEA and SFA research on the efficiency of microfinance institutions: A meta-analysis. World Development, 107, 176-188.

Gohar, R., \& Batool, A. (2015). Effects of corporate governance on performance of microfinance institutions: A case from Pakistan. Emerging Markets Finance and Trade, 51, 94-106.

Guichandut, P. (2018). Microfinance Barometer: is microfinance profitable? Retrieved from https:// group.bnpparibas/en/news/microfinance-barometer-2018-microfinance-profitable. Accessed on 20th November 2019.

Gutierrez-Goiria, J., San-Jose, L., \& Retolaza, J. L. (2017). Social efficiency in microfinance institutions: Identifying how to improve it. Journal of International Development, 29(2), 259-280.

Gutiérrez-Nieto, B., Serrano-Cinca, C., \& Mar Molinero, C. (2009). Social efficiency in microfinance institutions. Journal of the Operational Research Society, 60(1), 104-119.

Halouani, N., \& Boujelbene, Y. (2015). External governance and dual mission in the African MFIs. Strategic Change, 24, 243-265.

Hashim, M. J., Adeyemi, A. A., \& Alhabshi, S. M. (2018). Effects of intellectual capital on microfinance 'institutions' performance. In Proceedings of the 2nd Advances in Business Research International Conference (pp. 187-196). Springer, Singapore.

Hermes, N., \& Hudon, M. (2018). Determinants of the performance of microfinance institutions: A systematic review. Journal of Economic Surveys, 32(5), 1483-1513.

Hermes, N., Lensink, R., \& Meesters, A. (2011). Outreach and efficiency of microfinance institutions. World Development, 39(6), 938-948. 
Hossain, S., Galbreath, J., Hasan, M. M., \& Randøy, T. (2020). Does competition enhance the doublebottom-line performance of microfinance institutions? Journal of Banking and Finance, 113, 1-17.

Kamaluddin, A., \& Rahman, R. A. (2013). Intellectual capital profiles: Empirical evidence of Malaysian companies. International Review of Business Research Papers, 9(6), 83-101.

Kamukama, N., Ahiauzu, A., \& Ntayi, J. M. (2010). Intellectual capital and performance: Testing interaction effects. Journal of Intellectual Capital, 11(4), 554-574.

Kamukama, N., \& Sulait, T. (2017). Intellectual capital and competitive advantage in Uganda's microfinance industry. African Journal of Economic and Management Studies, 8(4), 498-514.

Kar, A. K., \& Rahman, S. (2018). Changes in total factor productivity and efficiency of microfinance institutions in the developing world: A non-parametric approach. Economic Analysis and Policy, $60,103-118$.

Kennedy, P. (2008). A guide to econometrics (6th ed.). John Wiley and Sons.

Khalique, M., Bontis, N., Bin Shaari, J. A. N., \& Isa, A. H. M. (2015). Intellectual capital in small and medium enterprises in Pakistan. Journal of Intellectual Capital, 16(1), 224-238.

Khalique, M., Shaari, N., Abdul, J., Isa, A. H. B. M., \& Samad, N. (2013). Impact of intellectual capital on the organizational performance of Islamic banking sector in Malaysia. Asian Journal of Finance and Accounting, 5(2), 75-83.

Ling, Y. H. (2012). The influence of intellectual capital on global initiatives. Vine, 42(1), 129-144.

Majumder, M. T. H. (2012). Human resource management practices and 'employees' satisfaction towards private banking sector in Bangladesh. International Review of Management and Marketing, 2(1), 52-58.

McCarty, T. A., \& Yaisawarng, S. (1993). Technical efficiency in New Jersey school districts. The Measurement of Productive Efficiency, Techniques and applications (pp. 271-287). Oxford University Press.

Mia, M. A. (2017). Determinants of total factor productivity in microfinance institutions: Evidence from Bangladesh. In Microfinance for Entrepreneurial Development (pp. 197-222). Palgrave Macmillan, Cham.

Mia, M. A. (2020). Participation of women in the South Asian microfinance industry: An observation. Journal of Public Affairs, 21(2), 1-10.

Mia, M. A., \& Chandran, V. G. R. (2016). Measuring financial and social outreach productivity of microfinance institutions in Bangladesh. Social Indicators Research, 127(2), 505-527.

Mia, M. A., \& Soltane, B. I. B. (2016). Productivity and its determinants in microfinance institutions (MFIs): Evidence from South Asian countries. Economic Analysis and Policy, 51, 32-45.

Microfinance Barometer. (2019). 10 Years already! A look back at the trends in microfinance. Retrieved from https://www.convergences.org/wp-content/uploads/2019/09/MicrofinanceBarometer-2019_web-1.pdf. Accessed on 15th August 2020.

Müller, O., \& Uhde, A. (2013). The impact of external governance quality on the economic and social success of microfinance institutions. International Journal of Monetary Economics and Finance, 6(2-3), 116-149.

Nimtrakoon, S. (2015). The relationship between intellectual capital, 'firms' market value and financial performance: Empirical evidence from the ASEAN. Journal of Intellectual Capital, 16(3), 587-618.

Nourani, M., Malim, N. A. K., \& Mia, M. A. (2020). Revisiting efficiency of microfinance institutions (MFIs): An application of network data envelopment analysis. Economic Research, 34(1), 1146-1169.

Ozkan, N., Cakan, S., \& Kayacan, M. (2017). Intellectual capital and financial performance: A study of the Turkish banking sector. Borsa Istanbul Review, 17(3), 190-198.

Pati, A. (2015). Are regulatory microfinance institutions of India better off than non-regulatory ones? A comparison of performance and sustainability. Paradigm, 19(1), 21-36.

Pinz, A., \& Helmig, B. (2015). Success factors of microfinance institutions: State of the art and research agenda. Voluntas: International Journal of Voluntary and Nonprofit Organizations, 26(2), 488-509.

Pulic, A. (1998). Measuring the performance of intellectual potential in knowledge economy. In $2 n d$ McMaster Word Congress on Measuring and Managing Intellectual Capital by the Austrian Team for Intellectual Potential (pp. 1-20).

Pulic, A. (2000). VAIC ${ }^{\mathrm{TM}}$-An accounting tool for IC management. International Journal of Technology Management, 20(5-8), 702-714.

Pulic, A. (2004). Intellectual capital — Does it create or destroy value?. Measuring Business Excellence, $8(1), 62-68$. 
Quayes, S., \& Joseph, G. (2017). Legal systems and performance of microfinance institutions. International Review of Applied Economics, 31(3), 304-317.

Roodman, D. (2009). How to do xtabond2: An introduction to difference and system GMM in Stata. The Stata Journal, 9(1), 86-136.

Sainz-Fernandez, I., Torre-Olmo, B., López-Gutiérrez, C., \& Sanfilippo-Azofra, S. (2015). Crisis in microfinance institutions: Identifying problems. Journal of International Development, 27(7), 1058-1073.

Simar, L., \& Wilson, P. W. (2007). Estimation and inference in two-stage, semi-parametric models of production processes. Journal of Econometrics, 136(1), 31-64.

Sinha, R. P., \& Pandey, P. (2019). Efficiency of microfinance institutions in India: A two-stage DEA approach. International Journal of Rural Management, 15(1), 49-77.

Soewarno, N., \& Tjahjadi, B. (2020). Measures that matter: An empirical investigation of intellectual capital and financial performance of banking firms in Indonesia. Journal of Intellectual Capital, 21(6), 1085-1106.

Stewart, T. A. (1997). Intellectual capital: The new wealth of organizations. Bantam Doubleday Dell Publishing Group. Inc.

Taylor, M. (2011). Freedom from poverty is not for free: Rural development and the microfinance crisis in Andhra Pradesh, India. Journal of Agrarian Change, 11(4), 484-504.

Turini, C. (2018). Microfinance barometer: Is microfinance profitable? Retrieved from https://group. bnpparibas/en/news/microfinance-barometer-2018-microfinance-profitable. Accessed on 20th November 2019.

Vidyarthi, H., \& Tiwari, R. (2019). Cost, revenue, and profit efficiency characteristics, and intellectual capital in Indian banks. Journal of Intellectual Capital, 21(1), 1-22.

Wernerfelt, B. (1984). A resource-based view of the firm. Strategic Management Journal, 5(2), 171-180.

Widiarto, I., \& Emrouznejad, A. (2015). Social and financial efficiency of Islamic microfinance institutions: A data envelopment analysis application. Socio-Economic Planning Sciences, 50, 1-17.

Wijesiri, M., \& Meoli, M. (2015). Productivity change of microfinance institutions in Kenya: A bootstrap Malmquist approach. Journal of Retailing and Consumer Services, 25, 115-121.

Wijesiri, M., Yaron, J., \& Meoli, M. (2017). Assessing the financial and outreach efficiency of microfinance institutions: Do age and size matter? Journal of Multinational Financial Management, 40, 63-76.

World Bank. (2019a). Economic growth, financial sector development, private sector development. Retrieved from https://datacatalog.worldbank.org/dataset/mix-market. Accessed on 11th January 2020.

World Bank. (2019b). World development indicators. Retrieved from https://databank.worldbank.org/ source/world-development-indicators. Accessed on 17th June 2019.

$\mathrm{Xu}$, J., \& Li, J. (2019). The impact of intellectual capital on 'SMEs' performance in China: Empirical evidence from non-high-tech vs. high-tech SMEs. Journal of Intellectual Capital, 20(4), 488-509.

Yalama, A., \& Coskun, M. (2007). Intellectual capital performance of quoted banks on the Istanbul stock exchange market. Journal of Intellectual Capital, 8(2), 256-271.

Zheng, C., \& Zhang, J. (2021). The impact of COVID-19 on the efficiency of microfinance institutions. International Review of Economics and Finance, 71, 407-423.

Publisher's Note Springer Nature remains neutral with regard to jurisdictional claims in published maps and institutional affiliations. 